\title{
Ratios of carbon, nitrogen and phosphorus in Pseudomonas fluorescens as a model for bacterial element ratios and nutrient regeneration
}

\author{
Thomas H. Chrzanowski*, Marcia Kyle \\ Department of Biology, PO Box 19498, The University of Texas at Arlington, Arlington, Texas 76019, USA
}

\begin{abstract}
Bacteria play a significant role in the nutrient dynamics of planktonic systems, yet their nutrient demands are poorly known. Here, we characterize the element ratios of a common freshwater bacterium relative to growth rate and nutrient availability. Pseudomonas fluorescens was grown in chemostats at dilution rates of $0.03,0.06$, and $0.09 \mathrm{~h}^{-1}$ Phosphorus (P) was supplied at approximately $5 \mu \mathrm{M}$ and nitrogen $(\mathrm{N})$ was supplied at varying concentrations to establish resource molar-N:P ratios $\left(S_{N: P}\right)$ ranging between 5:1 and 117:1 Carbon was supplied in excess. Chemostats were sampled at steady state, the element composition of cells $(Q)$ was determined, and element ratios $\left(Q_{X: Y}\right)$ were calculated. $Q_{C N}$ was 7.6:1 and varied little with respect to growth rate or the element composition of the medium. In contrast, $Q_{N: P}$ was variable and positively related to the $S_{N}$ until an upper limit of $\sim 21: 1$ was attained at a $S_{N . P}$ of 33:1. $Q_{C . p}$ mimicked $Q_{N . p}$ and was constrained by the fixed $Q_{C: N}$. P. fluorescens appeared to have a high capacity to accumulate $P$ and the data suggested that the organism may be capable of incorporating $\mathrm{P}$ above that required to meet metabolic demand ('luxury uptake'). Comparison of these data with previously published data revealed that the bacteria have a much greater potential to adjust their $Q_{\mathrm{N} p}$ when the N:P ratio of resources supporting growth is low (N scarce), than when the ratio is high ( $\mathrm{N}$ abundant). The $\mathrm{C}: \mathrm{N}: \mathrm{P}$ ratio of bacteria was found to vary between $52: 8: 1$ when $N$ was scarce relative to $P(N: P<40: 1)$, to as high as 163:25:1 when $N$ was abundant relative to $P$ $(N: P>40: 1)$.
\end{abstract}

KEY WORDS: Carbon - Nitrogen $\cdot$ Phosphorus - Nutrient regeneration

\section{INTRODUCTION}

'Despite the mystical properties of a liter of natural water, why should it be able to provide all of the organisms therein with the proper physical-chemical requirements for activity? There is no law of nature dictating that it should.' (Stevenson 1978).

Stevenson's rhetorical question reminds us that all organisms have particular demands for nutrients that must be met if they are to persist within the plankton. In essence, Stevenson touched upon a concept now known as ecological stoichiometry. Ecological stoichiometry focuses on the element composition (i.e. requirements) of organisms and how the ratio of elements available may subsequently influence competi-

•E-mail: chrz@albert.uta.edu tion (Hecky \& Kilham 1988), nutrient recycling (Sterner 1990, Sterner et al. 1992), and community structure (Elser et al. 1988)

Considerable effort has gone into defining element composition and nutrient requirements of phytoplankton (Hecky \& Kilham 1988 and references therein) and zooplankton (Baudouin \& Ravera 1972, Hessen et al. 1989, Andersen \& Hessen 1991, Sterner \& Hessen 1994). Models based on element ratios have been developed to predict the ratio of elements regenerated when herbivorous zooplankton having one element ratio graze phytoplankton of a greater or lesser element ratio (Hessen et al. 1989, Sterner 1990, Sterner et al. 1992, Urabe 1993). A critical feature of these models is the degree to which the herbivores regulate their element stoichiometry. Herbivores can regenerate the element(s) consumed in excess of metabolic demand with great efficiency. 
The development of similar theory encompassing the bacterioplankton and their predators is not as advanced because the element requirements of the bacterioplankton (Nagata 1986, Goldman et al. 1987a, Lee \& Fuhrman 1987, Martinussen \& Thingstad 1987. Vadstein \& Olsen 1989, Tezuka 1990, Nakano 1994b) and of the protozooplankton (Goldman et al. 1985, Andersen et al. 1986, Goldman et al. 1987b, Nakano 1994 a) are not well known. However, simple stoichiometric models of nutrient release by protozooplankton recognize that the nutrients released will be affected by the C:N:P ratio of bacterial prey (Goldman et al. 1987b, Bloem et al. 1988, Caron et al. 1988, Vadstein et al. 1993). Other studies focusing primarily on nutrient regeneration by bacteria alone generally assume that bacteria have a fixed element ratio (Reiners 1986 , Thingstad 1987) and focus on regeneration of $N$ as cells attempt to meet their demand for $C$ (Goldman et al. 1987a). Studies addressing nutrients regenerated by protozooplankton grazing bacteria have focused on P regeneration (Anderson et al. 1985, Bloem et al. 1988, Jürgens \& Güde 1990) or $N$ regeneration (Sherr et al. 1983, Anderson et al. 1985, Sherr et al. 1988, Goldman \& Dennett 1992) but generally tend to ignore how the ratio of these elements in both predator and prey may influence nutrient regeneration.

The cellular concentration of, and hence the demand for, $C, N$, and $P$ in bacteria increases as growth rate increases (Cooney et al. 1976, Vadstein \& Olsen 1989). However, $\mathrm{C}: \mathrm{N}$ appears to vary only slightly no matter the condition of growth (Bratbak 1985, Nagata 1986, Bremer \& Dennis 1987. Goldman et al. 1987a, Lee \& Fuhrman 1987). It is less clear, particularly with regard to $P$, how the ratio of elements will vary as a function of nutrient supply. Such information is pivotal to furthering our understanding of how bacteria and protozooplankton regenerate nutrients. This work represents a contribution to this understanding by defining the $C$, $N$, and P content of a cell type commonly isolated from freshwater, Pseudomonas fluorescens, and compares results to data available from a variety of bacteria.

\section{MATERIALS AND METHODS}

Pseudomonas fluorescens was grown in chemostats at 3 dilution rates $\left(0.03,0.06\right.$ and $0.09 \mathrm{~h}^{-1}$, doubling times of 8 to $23 \mathrm{~h}$ ). The composition of modified Tezuka medium ( $\mathrm{mg} \mathrm{l}^{-1}$ distilled water; $\mathrm{KCl}, 37 ; \mathrm{MgSO}_{4}, 130_{i}$ $\mathrm{CaCl}_{2}, 14 ; \mathrm{Fe}-\mathrm{Na}$ EDTA, 7; sodium acetate $680_{i}$ $\mathrm{NH}_{4} \mathrm{SO}_{4}, 0.53$ to $10.22 ; \mathrm{NaH}_{2} \mathrm{PO}_{4}, 0.69 ; \mathrm{pH}$ adjusted to between 7.0 and 7.2) (Tezuka 1990) fed to chemostats was altered to create a range in the N:P supply ratio $\left(S_{N}\right.$ ). The concentration of $N$ ranged between 38 and $700 \mu \mathrm{M}$. while $\mathrm{P}$ concentration was held at approxi- mately $5 \mu \mathrm{M}$. Carbon was always supplied in great excess $(\sim 10000 \mu \mathrm{M} \mathrm{C})$. The concentration of $\mathrm{C}, \mathrm{N}$, and $P$ in the medium supply and in cells was empirically determined (see below).

Chemostats. Each of three $1 \mathrm{l}$ chemostats (Applikon Instruments) operated at the same dilution rate, received medium having a different $S_{N}$. . Chemostats were inoculated with cells grown in batch culture on modified Tezuka medium of the same chemical composition as the chemostat medium. Chemostats were maintained at $25^{\circ} \mathrm{C}$, continually stirred and aerated, and sampled after steady-state was attained (determined from cell counts).

Analyses. Chemical composition of the medium was determined from triplicate samples drawn from the medium-supply reservoir. Organic carbon was oxidized with persulfate (Strickland \& Parsons 1972), and the resultant $\mathrm{CO}_{2}$ measured with an infrared analyzer (Horiba PIR 2000) and subsequently converted to moles of C. Phosphorus (as soluble reactive phosphorus, SRP) was determined according to the methods of Strickland \& Parsons (1972). Nitrogen (as $\mathrm{NH}_{4}{ }^{+}$) was determined using the procedures described by Solórzano (1969). Cells contained in triplicate samples drawn from a reactor were collected on pre-combusted glass-fiber filters (Whatman GF/F, nominal retention $0.7 \mu \mathrm{m}$ ) and rinsed with distilled water. The $\mathrm{C}$ and $\mathrm{N}$ content was determined using a CHN analyzer (Perkin-Elmer) and $P$ content was determined from persulfate digests and subsequent SRP analyses (Strickland \& Parsons 1972). Ratios of elements are reported as mole:mole. Cell concentration was determined by direct microscopic enumeration using epifluorescent microscopy with DAPI (Porter \& Feig 1980) as the fluorochrome. Cell volumes were determined from ocular measurements $(1875 \times)$ of at least 90 cells from each sample.

Regression analyses. Visual inspection of the data suggested the appropriate from of regression analyses. In cases where rectilinear models were suggested, 'piecewise regression with breakpoint' (CSS: Statistica, Statsoft, Inc.) was used. This analysis fits 2 linear models simultaneously and predicts the point of discontinuity (inflection point) while minimizing the sum of squares error for the entire model. Variables were assumed to be normally distributed.

\section{RESULTS AND DISCUSSION}

\section{General features of cultures}

Table 1 summarizes characteristics of both medium and cells for each of 22 experiments. P content of the medium varied between 3.9 and $7.3 \mu \mathrm{M}$ while $\mathrm{C}$ varied between 8778 and $12170 \mu \mathrm{M}$. The concentration of $\mathrm{N}$ 
Table 1. Elemental composition of medium and Pseudomonas fluorescens grown in chemostats. Value following \pm is the standard error from triplicate samples from a reactor. Ratios are mole:mole

\begin{tabular}{|c|c|c|c|c|c|}
\hline Experiment & $\begin{array}{c}\text { Growth rate } \\
\left(h^{-1}\right)\end{array}$ & $\begin{array}{l}\text { Medium } \\
\text { C:N:P }\end{array}$ & $\begin{array}{l}\text { Cell concentration } \\
\left(10^{10} \text { cells } 1^{-1}\right)\end{array}$ & $\begin{array}{l}\text { Cell volume } \\
\left(\mu \mathrm{m}^{3} \text { cell }^{-1}\right)\end{array}$ & $\begin{array}{l}\text { Cell } \\
\text { C:N:P }\end{array}$ \\
\hline 1 & 0.03 & $1206: 5: 1$ & $4.64 \pm 0.66$ & $0.54 \pm 0.1$ & $77: 10: 1$ \\
\hline 2 & 0.03 & $1882: 20: 1$ & $3.92 \pm 0.21$ & $0.60 \pm 0.1$ & $158: 14: 1$ \\
\hline 3 & 0.03 & $2474: 33: 1$ & $2.82 \pm 0.29$ & $0.66 \pm 0.1$ & $128: 18: 1$ \\
\hline 4 & 0.03 & $2544: 44: 1$ & $2.4 \pm 0.12$ & $0.62 \pm 0.1$ & $209: 23: 1$ \\
\hline 5 & 0.03 & $2058: 59: 1$ & $2.1 \pm 0.16$ & $0.71 \pm 0.1$ & $216: 26: 1$ \\
\hline 6 & 0.03 & $1781: 47: 1$ & $5.96 \pm 1.79$ & $0.72 \pm 0.1$ & $102: 27: 1$ \\
\hline 7 & 0.03 & $1581: 49: 1$ & $1.73 \pm 0.04$ & $0.85 \pm 0.2$ & $86: 15: 1$ \\
\hline 8 & 0.03 & $1567: 70: 1$ & $2.33 \pm 0.27$ & $0.72 \pm 0.1$ & $184: 23: 1$ \\
\hline 9 & 0.03 & $1616: 97: 1$ & $1.62 \pm 0.01$ & $0.73 \pm 0.1$ & $169: 22: 1$ \\
\hline 10 & 0.06 & $1882: 20: 1$ & $3.79 \pm 0.16$ & $0.65 \pm 0.1$ & $141: 18: 1$ \\
\hline 11 & 0.06 & $2475: 32: 1$ & $2.93 \pm 0.22$ & $0.64 \pm 0.1$ & $144: 23: 1$ \\
\hline 12 & 0.06 & $2400: 43: 1$ & $2.15 \pm 0.12$ & $0.77 \pm 0.1$ & $124: 21: 1$ \\
\hline 13 & 0.06 & $1781: 46: 1$ & $4.8 \pm 0.19$ & $0.71 \pm 0.1$ & $149: 25: 1$ \\
\hline 14 & 0.06 & $2189: 65: 1$ & $1.81 \pm 0.40$ & $0.72 \pm 0.1$ & $182: 24: 1$ \\
\hline 15 & 0.06 & $1753: 54: 1$ & $1.42 \pm 0.02$ & $0.76 \pm 0.2$ & $171: 22: 1$ \\
\hline 16 & 0.06 & $1565: 75: 1$ & $1.3 \pm 0.19$ & $0.75 \pm 0.1$ & $161: 20: 1$ \\
\hline 17 & 0.06 & 1600:106:1 & $2.4 \pm 0.40$ & $0.72 \pm 0.1$ & $150: 19: 1$ \\
\hline 18 & 0.09 & $2372: 43: 1$ & $3.21 \pm 0.03$ & $0.67 \pm 0.1$ & $107: 19: 1$ \\
\hline 19 & 0.09 & $2058: 59: 1$ & $0.99 \pm 0.20$ & $0.69 \pm 0.1$ & $120: 17: 1$ \\
\hline 20 & 0.09 & $1894: 58: 1$ & $1.34 \pm 0.05$ & $0.92 \pm 0.2$ & $134: 18: 1$ \\
\hline 21 & 0.09 & $1872: 87: 1$ & $0.96 \pm 0.06$ & $0.87 \pm 0.2$ & $102: 16: 1$ \\
\hline 22 & 0.09 & $1884: 117: 1$ & $1.09 \pm 0.10$ & $0.77 \pm 0.1$ & $104: 16: 1$ \\
\hline
\end{tabular}

was experimentally manipulated and varied between 38.1 and $730.3 \mu \mathrm{M}$. The $\mathrm{C}: \mathrm{N}: \mathrm{P}$ ratio of the medium reflects the attempts to ensure an ample supply of $C$ while adjusting N:P. In all experiments C:P supplied to cells exceeded 1200:1 while N:P varied between 5:1 and $117: 1$.

\section{Relationships among elements and cellular ratios}

Element content of the cells was normalized to cell volume and expressed as cell quota $\left(Q_{C}, Q_{N}\right.$ or $Q_{\mathrm{p}}$, fmol $\mu \mathrm{m}^{3}$; Droop 1974). Relationships among elements are depicted as 'bubble plots' in Figs. 1, 2 \& 3. Bubble plots permit the representation of 3 variables simultaneously. The ordinate and abscissa are presented in normal fashion but the 'bubbled' variable (a continuous variable) is presented as a circle whose numerical value is proportional to bubble size.

The relationship between $Q_{C}$ and $Q_{N}$ was linear (Fig. 1, $\mathrm{r}^{2}=0.91, \mathrm{n}=22, \mathrm{p}<0.001$ ). The slope of this relationship, $7.6 \pm 0.5$, is the cellular C:N functional ratio $\left(Q_{C N}\right.$; the term 'functional ratio' distinguishes a relationship determined from the slope of a regression from a 'ratio' which is simply the quotient obtained by dividing cell quotas) and is within the range of $\mathrm{C}: \mathrm{N}$ ratios (2.8 to 17.2) reported for a wide variety of bacteria (freshwater and marine, chemoautotrophs and heterotrophs) grown under an equally wide variety of conditions (pure and mixed cultures,
Qc (fmoles carbon $\mu \mathrm{m}^{-3}$ )

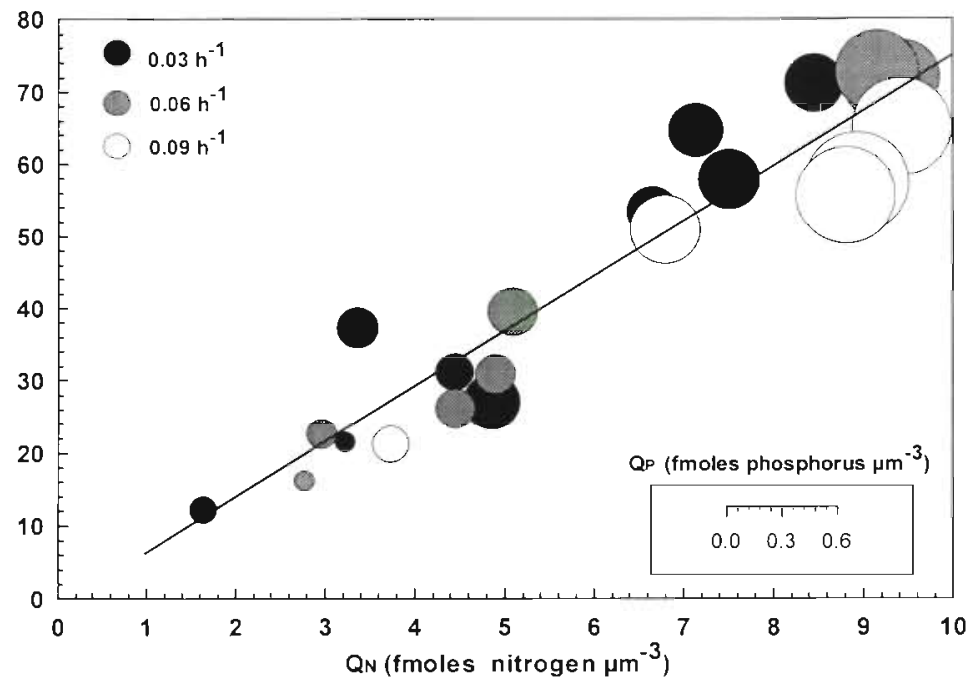

Fig. 1. Pseudomonas fluorescens. Relationships among the cell quotas of carbon $\left(Q_{C}\right)$, nitrogen $\left(Q_{N}\right)$, and phosphorus $\left(Q_{P}\right.$, bubbled vector) for bacteria grown at 3 dilution rates. The regression line fits $Q_{C}$ to $Q_{N}$ [slope $=$

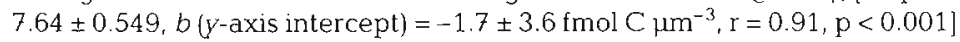


aerobic and anaerobic) (Bratbak 1985, Nagata 1986. Lee \& Fuhrman 1987, Goldman et al. 1987 a, BrinchIversen \& King 1990, Tezuka 1990, Kroer 1994). When all data, our individual measures and those cited above, were considered ( $\mathrm{n}=84$ ), the $Q_{\mathrm{CN}}$ ratio of bacteria averaged $6.46 \pm 0.27$. The low variability is not surprising as $Q_{C N}$ appears to vary only slightly with growth conditions (Bratbak 1985, Nagata 1986, Bremer \& Dennis 1987, Goldman et al. 1987 a, Lee \& Fuhrman 1987).

Fig. 2 depicts changes in $Q_{C}$ as a function of $Q_{p}$ and growth rate with $Q_{N}$, the bubbled vector. $Q_{C}$ increased as a function of $Q_{p}$ until cells attained approximately

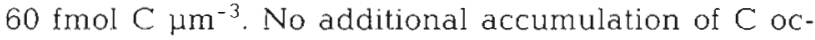
curred even though cells continued to accumulate P. $Q_{C}$ was mirrored by $Q_{N}$ (increasing bubble size until $Q_{C}$ constant, then bubble size constant) and reflects the constant $Q_{C: N}$ (see above). The $Q_{C}$ and $Q_{p}$ data were fit to a regression model to determine the slope of the relationship prior to the plateau as well as the inflection point of the curve (piecewise regression with breakpoint, $r=0.89, n=22$ ). Below a $Q_{p}$ of $0.37 \mathrm{fmol}$ $P \mu \mathrm{m}^{-3}$ the functional $Q_{C: P}$ was 200:1, but above a $Q_{\mathrm{P}}$ of $0.37 \mathrm{fmol} \mathrm{P}_{\mathrm{fm}}^{-3}$ the $Q_{\mathrm{CP}}$ decreased to as low as $111: 1$.

There is a considerable body of literature concerning the ratio of $C: P$ in bacteria. While variable, the $C: P$ ratio for cells grown under $\mathrm{C}$ or mineral limitation

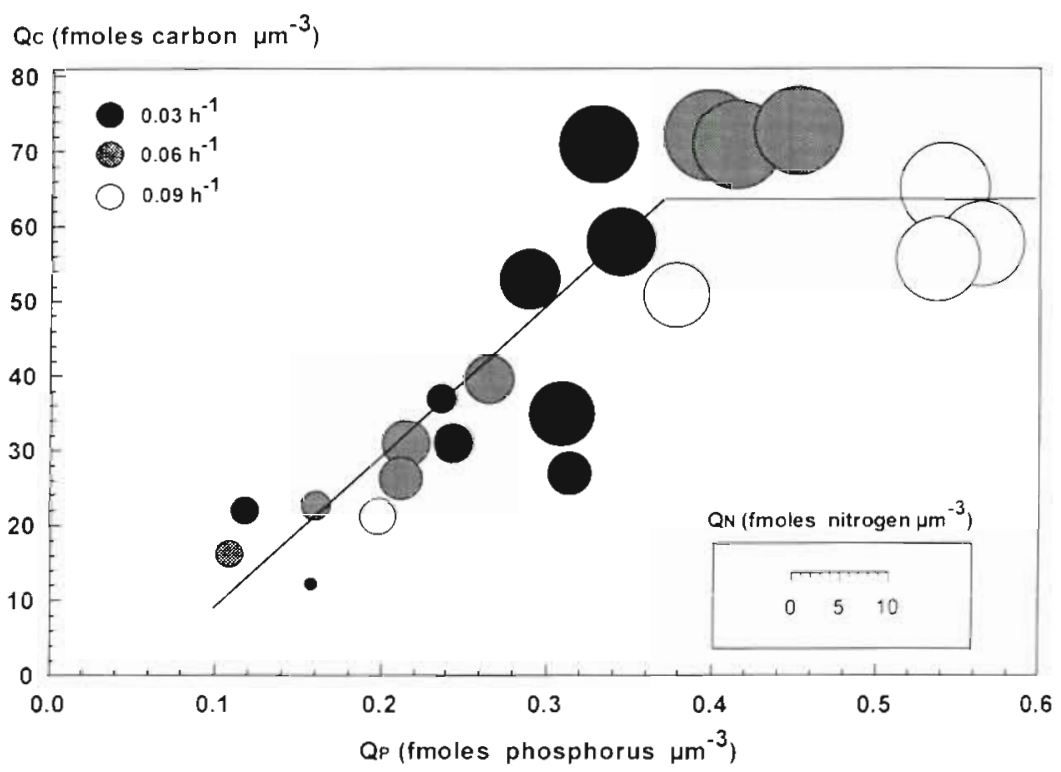

Fig. 2. Pseudomonas fluorescens. Bubble plot showing the relationshups among the cell quotas of carbon $\left(Q_{C}\right)$, phosphorus $\left(Q_{p}\right)$, and nitrogen $\left(Q_{N}\right.$, bubbled vector) for bacteria grown at 3 dilution rates. The regression line (piecewise regression with breakpoint) fits $Q_{r}$ to $Q_{\mathrm{p}}[\mathrm{r}=0.89 ; \mathrm{B} 1$ (y-axis intercept $)=-11.3 \pm 0.87$ fmol C $\mu \mathrm{m}, p<0.21$; B2 $(y$-axis value at breakpoint $)=63.6 \pm 3.4 \mathrm{fmol} \mathrm{C} \mathrm{mm}^{-3}$,

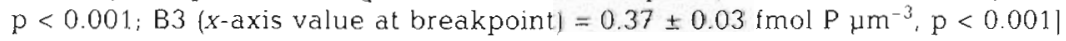

other than P falls below $50: 1$ (Dicks \& Tempest 1966 , Tempest et al. 1968, van Veen \& Paul 1979, Bratbak 1985, Jürgens \& Güde 1990). Cells grown under P limitation generally have C:P ratios typically in the range of 100:1 (Dicks \& Tempest 1966, Tempest et al. 1968, Vadstein et al. 1988, Jürgens \& Güde 1990).

The relationship between $Q_{N}$ and $Q_{p}$ (QN.p; Fig. 3) has been rarely considered for bacteria (van Veen \& Paul 1979, Bratbak 1985, Goldman et al. 1987a, Tezuka 1990). This relationship was similar to that of functional $Q_{C \text { P }}$ owing to the constant $Q_{C: N}$. Thus, $Q_{N}$ increased as a linear function of $Q_{p}$ until cells reached approximately $9 \mathrm{fmol} \cap \mathrm{Nm}^{-3}$ Above this level $Q_{N}$ remained constant while $Q_{P}$ continued to increase. The data were fit to a regression model (as above) to determine the $Q_{N: P}$ above and below the inflection point. The functional $Q_{\mathrm{N}}$ below the inflection point was 24.5:1 and decreased to a low of $16: 1$ above the inflection point. There are few data points to the right of the inflection point of the curve (Fig. 3); thus there is a high degree of statistical uncertainty associated with the coefficients (an ill-conditioned model).

\section{$Q_{\mathrm{N}: \mathrm{P}}$ and $S_{\mathrm{N}: \mathrm{P}}$}

The experimental design allowed a comparison of

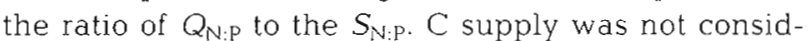
ered in this analysis since $C$ was always supplied in great excess.

The relationship between $Q_{\mathrm{N}, \mathrm{P}} Q_{\mathrm{C}}$ and $S_{N . P}$ is shown in Fig. 4. $S_{N: P}$ ranged from 5:1 to $117: 1$ while $Q_{\mathrm{N} . \mathrm{P}}$ spanned a relatively narrow range between 10:1. and 27:1. The $Q_{N P}$ increased as $S_{N . p}$ increased until $S_{\mathrm{N} . \mathrm{p}}$ was 33:1 after which QNp remained at 21:1 (Fig. 4, breakpoints from non-linear regression analysis). It is apparent from these data that Pseudomonas fluorescens did not accumulate elements simply as a function of supply; if this were the case, the relationship between $Q_{\mathrm{N}: \mathrm{P}}$ and $S_{\mathrm{NP}}$ would fall on a line having a slope of 1 (also shown in Fig. 4).

Nutrient limited growth of bacteria may be described by the empirical relationship derived by Droop (1974):

$$
\mu=\mu_{\max }^{\prime} \frac{Q-Q_{0}}{Q}
$$

where $Q_{0}$ is the cell quota of element $x$ when $\mu=0$ (i.e the minimum cell quota) and $\mu^{\prime}$ max is the maximum apparent specific growth rate at infinite $Q$ 


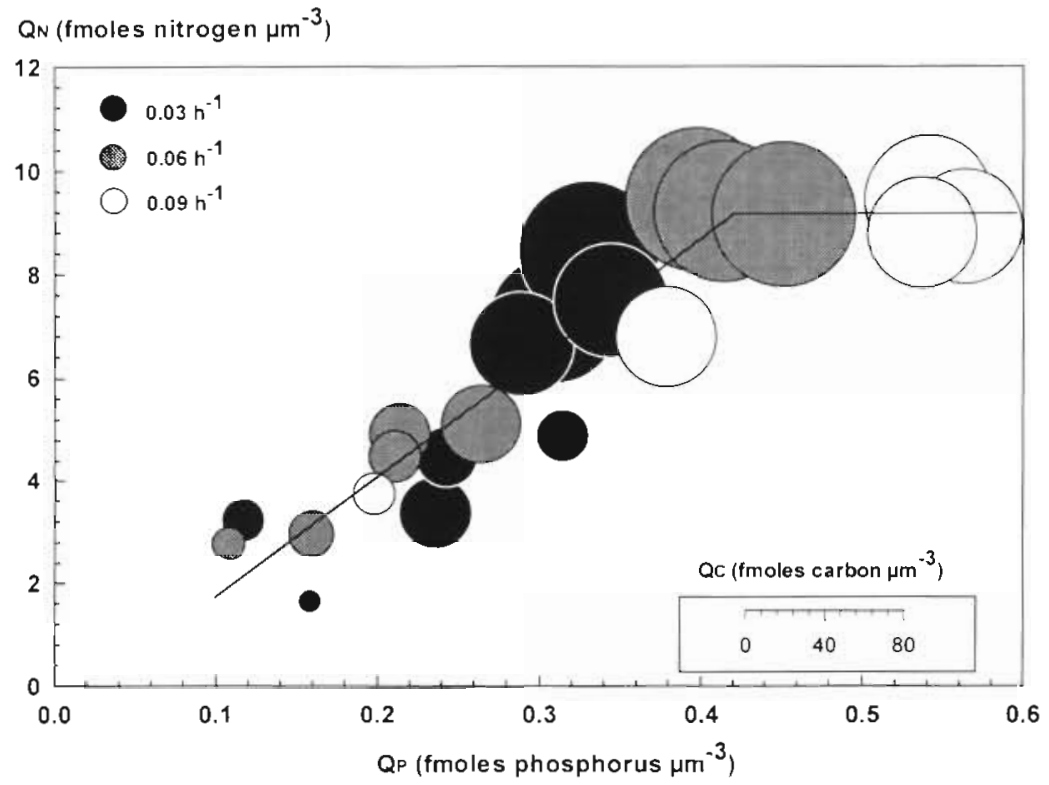

Fig. 3. Pseudomonas fluorescens. Relationship among the cell quotas of nitrogen $\left(Q_{N}\right)$, phosphorus $\left(Q_{p}\right)$, and carbon $\left(Q_{C}\right.$, bubbled vector) for bacteria grown at 3 dilution rates. The regression line (piecewise regression with breakpoint) fits $Q_{\mathrm{N}}$ to $Q_{\mathrm{P}}[\mathrm{r}=0.94 ; \mathrm{B} 1$ (y-axis intercept $)=-0.57 \mathrm{fmol} \mathrm{N} \mu \mathrm{m}^{-3} ; \mathrm{B} 2(y$-axis value at breakpoint) $=9.08 \mathrm{fmol} \mathrm{N} \mathrm{mm}^{-3} ; \mathrm{B} 3$ ( $X$-axis value at breakpoint) $=$ $0.42 \mathrm{fmol} \mathrm{P} \mathrm{mm}^{-3}$; see text for explanation of statistical uncertainty associated with this model]

(Droop 1974). Estimates of $\mu_{\max }^{\prime} Q_{0 p}$, and $Q_{0 N}$ (Table 2) were determined from linear regression of $\mu Q_{X}$ on $Q_{X}$ (Droop 1974) where $\mu Q_{X}$ and $Q_{x}$ were determined for each experiment then averaged by growth rate.

The $Q_{0 P}\left(0.19\right.$ fmol $\left.P \mu \mathrm{m}^{-3}\right)$ was approximately 20 -fold less than $Q_{0 \mathrm{~N}}$

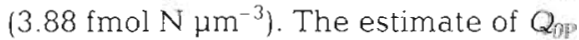
when normalized to $Q_{C}$ was similar to that reported for mixed cultures of bacteria grown under various conditions (Vadstein \& Olsen 1989). The ratio of Qun:p (20.4:1) may approach the maximum $Q_{N}$.P that Pseudomonas fluorescens will attain since $Q_{\mathrm{N} \text { : }}$ may be expected to decrease as growth rate increases and cells accumulate P-rich constituents (such as RNA, also see Turpin 1988). The trend towards lower $Q_{\mathrm{N}}$ :P at high growth rate may be seen in the data presented in Fig. 4. At similar values of $S_{N \text { :p }}$ the $Q_{N . P}$ ratio of cells grown at $0.09 \mathrm{~h}^{-1}$ tended to be lower than the $Q_{\text {N:P }}$ of cells grown at slower rates. Growth rates in these experiments were deliberately set low to mimic growth rates typical of natural assemblages. Generation times ranged between 8 and $23 \mathrm{~h}$ and, if $\mu_{\max }^{\prime}$ is taken as an estimate of the true $\mu_{\max }$, then the most rapid growth rate $\left(0.09 \mathrm{~h}^{-1}\right)$ was only about $50 \%$ of maximum potential growth rate (i.e. $\mu: \mu_{\text {max }}^{\prime}=0.56$ ). $Q$ is influenced by growth rate as well as element composition of the resource supply.

One of the more surprising findings concerns the ability of the cells to accumulate C (Fig. 4). Below a $S_{N}$ p of 40:1, $Q_{C}$ remained below $40 \mathrm{fmol} C \mu \mathrm{m}^{-3}$ (bubbled vector). $Q_{C}$ increased (more than doubled) near the point where

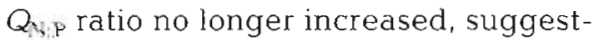
ing that cells continued to accumulate $N$ (due to a constant $Q_{\mathrm{C}: \mathrm{N}}$ ) and maintained $Q_{\text {N.P }}$ with continued accumulation of $P$ ('luxury uptake'?, see below) until a fixed ratio was attained. Thus element composition of cells was more likely to be affected by growth rate than by resource supply above an $S_{\mathrm{N} \text { : }}$ of 40:1. Data encompassing a much wider range of growth rates (where $\mu$ : $\mu_{\max }$ approaches 1) are required to determine the range in $Q_{\text {N }}$ that might be expected.

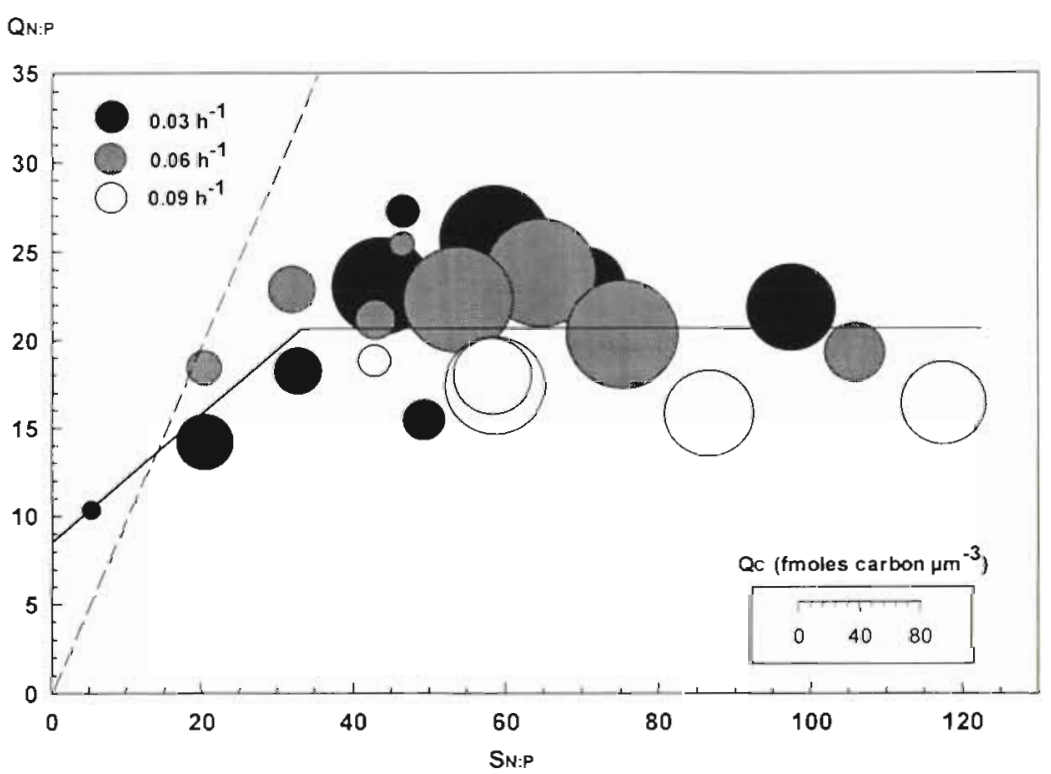

Fig. 4. Relationship among the ratio of nitrogen and phosphorus supplied to cells $\left(S_{\mathrm{N}: \mathrm{P}}\right)$, the ratio of nitrogen and phosphorus accumulated by cells $\left(Q_{\mathrm{N}: \mathrm{P}}\right)$, and the cell carbon cell quota $\left(Q_{C}\right.$, bubbled vector). Ratios are mole:mole. The regression line (solid line, piecewise regression with breakpoint) fits $Q_{N: P}$ to $S_{N: P}$ $\lfloor=0.61 ; \mathrm{B} 1$ ( $y$-axis intercept $)=8.59 \pm 5.03, \mathrm{p}<0.11 ; \mathrm{B} 2(y$-axis value at breakpoint $)=20.88 \pm 0.94, \mathrm{p}<0.001 ; \mathrm{B} 3$ ( $\mathrm{x}$-axis value at breakpoint $)=32.90 \pm 12.91$.

$p<0.02$. The dashed line represents a $1: 1$ ratio between $Q_{v}$ and $S_{\mathrm{v} p}$ 
Table 2. Pseudomonas fluorescens. Kinetic constants and the ratio of the minimum cell quotas of $\mathrm{N}$ and $\mathrm{P}$

\begin{tabular}{|lcccc|}
\hline Element & $\mu\left(\mathrm{h}^{-1}\right)$ & $Q\left(\mathrm{fmol} \mu \mathrm{m}^{-3}\right)$ & $\mu_{\max }^{\prime}\left(\mathrm{h}^{-1}\right)$ & $Q_{01}\left(10^{-10} \mu \mathrm{mol}_{\mu \mathrm{m}}^{-3}\right)$ \\
\hline Nitrogen & 0.03 & 4.55 & 0.168 & 3.88 \\
& 0.06 & 6.56 & & \\
Phosphorus & 0.09 & 7.89 & 0.161 & 0.19 \\
& 0.03 & 0.26 & & \\
& 0.06 & 0.28 & & \\
\hline
\end{tabular}

Pseudomonas fluorescens appears to have a great capacity to accumulate $P$. To determine if these findings were characteristic of bacteria in general, $Q_{N}$. was plotted against $S_{N}$ for all studies where these data could be extracted (Fig. 5). Data were available for pure and mixed cultures of both marine and freshwater bacteria, but there are few data above an $S_{\mathrm{N}: \mathrm{p}}$ of 50:1 and cells were grown under various forms of mineral limitation in both batch cultures and chemostats. Thus, considerable variability was introduced into the data set from which Fig. 5 was generated. Neverthe-

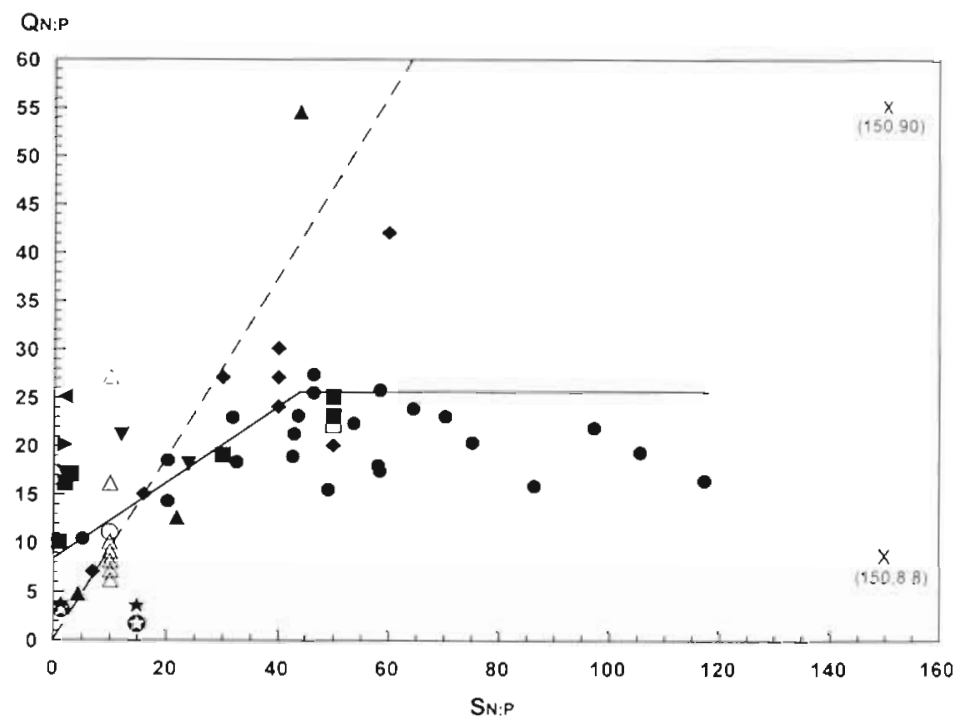

Fig. 5. Relationship between the ratio of nitrogen and phosphorus supplied to cells ( $\left.S_{\mathrm{N}}\right)$ and the ratio of $\mathrm{N}$ and $\mathrm{P}$ accumulated by cells $\left(Q_{\mathrm{N} p}\right)$ for Pseudomonas fluorescens ( this study), bacteria isolated from Lake Biwa ( $\bullet$, Tezuka 1990; $\mathbf{\square}$ Nakano 1994b), mixed assemblages of marine bacteria $(\triangle$. Goldman et al. $1987 a ; 0$. Andersen et al. 1986 ; 0 . Bratbak 1985), an unidentified marine bacteria ( $\mathbf{\Delta}$, Eccleston-Parry \& Leadbeater 1995), Pseudomonas halodurans ( $\square$, Andersen et al. 1986), Escherichia coli ( $\mathbf{\nabla}$, Nakano 1994b), P fluorescens ( Nakano 1994b), Flavobacterium ferrugineum (4, Nakano 1994b), and P. putida ( $\star$, Bratbak 1985). Two outlying data points ( $x$, Bratbak 1985) were excluded from analysis. Ratios are mole:mole. The regression line for $\mathrm{N}=65$ (solid Lne, piecewise regression with breakpoint) fits all data $[r=0.52, B 1(y$ axis intercept $)=8.4 \pm 2.8, \mathrm{p}<0.001 ; \mathrm{B} 2$ ( $\mathrm{y}$-axis value at breakpoint $)=$ $25.6 \pm 2.4, p<0.004 ; 133$ ( $x$-axis value at breakpoint $)=43.9 \pm 13.3, p<$ 0.0021 . The dashed line represents a $1: 1$ ratio between $Q_{N p}$ and $S_{N p}$ less, the data reveal that $Q_{\mathrm{N}}$ p rarely exceeds $-25: 1$ and that bacteria appear to have a much greater potential to adjust the $Q_{N . P}$ ratio when $N$ is scarce relative to $P$ (low $S_{N p}$ ) than when $\mathrm{N}$ is abundant relative to $\mathrm{P}$ (high $S_{N}$ p). Bacteria may approach a stable $Q_{N}$ p when the $S_{\mathrm{N} p}$ exceeds 40:1. When the range of $Q_{N \text { P }}$ is considcrcd (regression model, see Fig. 5), and the $Q_{C . N}$ is assumed fixed at 6.5:1 (average of 84 estimates, see above), bacteria may assume a C:N:P ratio as low as $52: 8: 1$ when $N$ is scarce relative to $P$, or as high as 63:25:1 when $N$ is abundant relative to $P$.

$P_{\text {seudomonas fluorescens regulated } \mathrm{N} \text { con- }}$ tent below a $Q_{\mathrm{N} . \mathrm{P}}$ of about 20:1 (determined from regression with breakpoint, and from the Droop relationship). This ratio may fall to lower values at higher growth rates (Fig. 4; Turpin 1988). If we assume the cultures represented slow growing cells with a $Q_{0 \mathrm{~m}}$ of 20:1, then an $S_{\text {N p }}$ of 33:1 (Fig. 4) was required for cells to attain the $Q_{\text {ON.P }}$ of $20: 1$ This implies (1) that cells may have a nitrogen assimilation efficiency of about $60 \%$ (the ratio of supply $N$ to $Q_{0 N}$ at $Q_{0 N p}$ of $20: 1$ ), and consequently, (2) that cells should experience $N$ limitation below an $S_{\mathrm{N}: \mathrm{P}}$ of $33: 1$ or a. $Q_{\mathrm{N} . \mathrm{p}}$ of 20:1. Extending this to data presented in Fig. 5, we speculate that bacteria having $Q_{\mathrm{N}: P}$ ratios below about 25:1 (inflection point of the regression line) should experience some degree of $\mathrm{N}$ limitation. Data presented by Elser et al. (1995, their Fig. 6) support this hypothesis. They found that bacteria in Canadian Shield lakes shifted from $\mathrm{N}$ incorporation at cellular N:P ratios below 20:1, to $N$ release at cellular $N: P$ ratios $>25: 1$

One potential factor that may influence the interpretation of our data concerns the ability of bacteria to store elements above that required to meet metabolic demands. Some bacteria have been reported to store carbon (as glycogen, poly- $\beta$-hydroxybutyrate, or polyhydroxyalkanoates) and phosphorus (as polyphosphate crystals) (Dawes \& Senior 
1973). Glycogen and poly- $\beta$-hydroxybutyrate are believed to be formed when cells have an ample supply of C but lack $N$, while polyphosphate is thought to be formed when cells have ample supply of $C$ and $P$ but lack $N$ (Ingraham et. al. 1983). It seems unlikely that such storage could account for the increase in $Q_{c}$ above an $S_{N \text { p }}$ of $40: 1$ (Fig. 4) since $N$ was never fully depleted from cultures with an $S_{\mathrm{N}: p}>10: 1$ (Table 1), and cells continued to accumulate both $N$ and $P$ at the same time as $Q_{C}$ increased (Fig 4). Polyphosphates should not have formed under the experimental conditions since $P$ was in short supply and synthesis of polyphosphates is inhibited during nucleic acid synthesis (Dawes \& Senior 1973). Direct microscopic observation of cells did not reveal the presence of polyphosphate crystals at any time. In separate experiments using batch cultures, crystals resembling polyphosphate crystals formed within cells only when the initial $S_{\backslash \text {.p }}$ was $<44.5: 1$ and cells were grown to late stationary phase.

Although polyphosphate crystals were not apparent within cells grown in our chemostats, the data suggest that Pseudomonas fluorescens may be capable of incorporating $\mathrm{P}$ above that required to meet metabolic demand ('luxury uptake'). Consider the data presented in Fig 1. In this plot, $Q_{p}$ is 'bubbled' against $Q_{C}$ and $Q_{N}$. The relationship between $Q_{C}$ and $Q_{N}$ is linear and indicates a fixed element ratio; however, $Q_{\mathrm{P}}$ increased at high values of $Q_{C}$ and $Q_{N}$ (not the ratio of $\mathrm{C}: \mathrm{N}$ ) even for cells grown at the same growth rate. A similar conclusion may be drawn from Fig. 2, where $Q_{p}$ continues to increase while $Q_{N}$ remains constant. Since the concentration of $\mathrm{P}$ fed to reactors was approximately the same from experiment to experiment, cells had the same opportunity to accumulate $P$ at low $Q_{C}$ and $Q_{N}$ as at high $Q_{C}$ and $Q_{N}$. Thus, the increased accumulation of $P$ at high $Q_{C}$ and $Q_{N}$ is suggestive of luxury uptake.

Pseudomonas fluorescens, as well as several other bacteria, appear to have a high capacity to accumulate $P$ and this suggests that aquatic bacteria should not be expected to regenerate $P$ unless the N:P ratio of the resource(s) supporting growth is less than about 25:1 (inflection of regression line in Fig. 5). The corollary suggests that bacteria would regenerate $N$ or simply not utilize $\mathrm{N}$ when the $\mathrm{N}$ :P ratio of the resource(s) supporting growth is greater than about 25:1. As a result of the variability associated with slope of the regression line there is some variability associated with estimates of when cells switch from $\mathrm{N}$ to $\mathrm{P}$ limitation. The slope is determined by regression coefficients B1 and B3 and the $\mathrm{SE}$ of $\mathrm{B} 3$ is large ( $30 \%$ of the estimate; Fig. 5). If variability in B3 is taken into account, bacteria would appear to shift from $N$ to $P$ limitation at an $S_{N: P}$ between 30:1 and 55:1.
Bacteria appear to accumulate $\mathrm{N}$ and $\mathrm{P}$ as a function of both the ratio of these nutrients in the resource pool and growth rate. This information not only allows for speculation concerning the elements potentially regenerated by bacteria, but also permits some speculation concerning the regeneration of elements contained within bacteria. Regeneration of bacterial $\mathrm{N}$ and $P$ should in turn reflect the element composition and, perhaps, growth rate of protozoan bacterivores. If protozoa homoeostatically regulate element composition, then nutrient regeneration should reflect not only the fixed element ratio of the protozoan, but to a much greater extent, the element composition of the resource pool supporting the bacterial prey. If, however, protozoan bacterivores do not homoeostatically regulate element composition but accumulate nutrients in a manner similar to bacteria, then prediction of the nutrients regenerated becomes a more complex problem. The element(s) regenerated by protozoa should reflect the ratios of elements supporting bacteria, the bacterial growth rate, the element ratio of the protozoan predator and, perhaps, the protozoan growth rate.

Acknowledgements. Several years of stimulating collaboration with Bob Sterner led us to pursue this work. His influence upon our thought processes is quite apparent and we gratefully acknowledge him as a key element in our stoichiometry. Jim Elser, Jim Grover, and Jotaro Urabe provided valuable comments on an early version of the manuscript. We thank Sharon Barnes for her assistance with maintaining the chemostats and her help with the nutrient chemistry. This work was supported by grant DEB-9119781 from the National Science Foundation and was submitted in partial fulfillment of the requirements for the MS degree of M.K

\section{LITERATURE CITED}

Andersen OK, Goldman JC, Caron DA, Dennett MR (1986) Nutrient cycling in a microflagellate food chain: III. Phosphorus dynamics. Mar Ecol Prog Ser 31:47-55

Andersen T, Hessen D (1991) Carbon, nitrogen, and phosphorus content of freshwater zooplankton. Limnol Oceanogr $36: 807-814$

Anderson A, Lee C, Azam F, Hagström \& (1985) Release of amino acids and inorganic nutrients by heterotrophic marine microflagellates. Mar Ecol Prog Ser 23:99-106

Baudouin MF, Ravera O (1972) Weight, size, and chemical composition of some freshwater zooplankton; Daphnia hyalina (Leydig). Limnol Oceanogr 17:645-649

Bloem J, Starink M, Bar-Gilissen MJB, Cappenberg TE (1988) Protozoan grazing, bacterial activity, and mineralization in two-stage continuous cultures. Appl Environ Microbiol 54 3113-3121

Bratbak G (1985) Bacterial biovolume and biomass estimations. Appl Environ Microbiol 49:1488-1493

Bremer H, Dennis PP (1987) Modulation of chemical composition and other parameters of the cell by growth rate. In: Neidhardt FC (ed) Escherichia coli and Salmonella typhimurium: cellular and molecular biology. Am Soc Microbiol, Washington DC, p 1527-1542 
Brinch-Iversen J, King GM (1990) Effects of substrate concentration, growth state, and oxygen availability on relationships among bacterial carbon, nitrogen, and phospholipid phosphorus content. FEMS Microbiol Ecol 74:345-356

Caron DA, Goldman JC, Dennett MR (1988) Experimental demonstration of the roles of bacteria and bacterivorous protozoa in plankton nutrient cycles. Hydrobiologia 159:27-40

Cooney CL, Wang DIC, Mateles RI (1976) Growth of Enterobacter derogenes in a chemostat with double nutrient limitations. Appl Environ Microbiol 31:91-98

Dawes EA. Senior PJ (1973) The role and regulation of energy reserve polymers in microorganisms. Adv Microb Physiol 10:135-266

Dicks JW, Tempest DW (1966) The influence of temperature and growth rate on the quantitative relationship between potassium, magnesium, phosphorus and ribonucleic arid of Aerobacter aerogenes growing in a chemostat. J Gin Microbiol 45:547-557

Droop MR (1974) The nutrient status of algal cells in continuous culture. J Mar Biol Ass UK 54:825-855

Eccleston-Parry JD, Leadbeater BSC (1995) Regeneration of phosphorus and nitrogen by four species of heterotrophic nanoflayelldtes feeding on three nutritional statcs of a single bacterial strain. Appl Environ Microbiol 61:1033-1038

Elser JJ, Chrzanowski TH, Sterner RW, Schampel JH, Foster DK (1995) Elemental ratios and the uptake and release of nutrients by phytoplankton and bacteria in three lakes of the Canadian Shield. Microb Ecol 29:145-162

Elser JJ, Elser MM, Mackay NA, Carpenter SR (1988) Zooplankton-mediated transitions between $\mathrm{N}$ and $\mathrm{P}$ limited algal growth. Limnol Oceanogr 33:1-14

Goldman JC. Caron DA, Andersen OK, Dennett MR (1985) Nutrient cycling in a microflagellate food chain: I. Nitrogen dynamics. Mar Ecol Prog Ser 24:231-242

Goldman JC. Caron DA, Dennett MR (1987a) Regulation of gross growth efficiency and ammonium regeneration in bacteria by substrate C:N ratio. Limnol Oceanogr 2: 1239-1252

Goldman JC, Caron DA, Dennett MR (1987b) Nutrient cycling in a microflagellate food chain: IV. Phytoplanktonmicroflagellate interactions. Mar Ecol Prog Ser 38:75-87

Goldman JC, Dennett MR (1992) Phagotrophy and $\mathrm{NH}_{4}$ regeneration in a three-member microbial food loop. J Plankton Res 14:649 663

Hecky RE, Kilham P (1988) Nutrient limitation of phytoplankton in freshwater and marine environments: a review of recent evidence on the effects of enrichment. Limnol Oceanogr 33:796-822

Hessen DO, Lyche A, Andersen T (1989) Differential grazing and resource utilization of zooplankton in a humc lake. Arch Hydrobiol 114:321-348

Ingraham JL, Maaloe O. Neidhardt FC (1983) Growth of the bacterial cell. Sinauer, Sunderland, MA

Jürgens K, Gude H (1990) Incorporation and release of phosphorus by planktonic bacteria and phagotrophic flagellates. Mlar Ecol Prog Ser 59:271-284

Kroer N (1994) Relationships betwen biovolume and carbon and nitrogen content of bacterioplankton. FEMS Microbiol Ecol 13:217-224

Lee S. Fuhrman JA (1987) Relationships between biovolume and biomass of naturally derived marine bacterioplankton. Appl Environ Microbiol 53:1298-1303

Martinussen I, Thingstad TF (1987) Utilization of N, P and organic $C$ by heterotrophic bacteria. II. Companson of experiments and a mathematical model. Mar Ecol Prog Ser 37:285-293

Nagata T (1986) Carbon and nutrogen content of natural planktonic bacteria. Appl Environ Microbiol 52:28-32
Nakano S (1994a) Rates and ratios of nitrogen and phosphorus released by a bacterivorus flacjellate. Jpn J Limnol 55: $115-123$

Nakano S (1994b) Carbon-nitrogen-phosphorus ratios and nutrient regeneration of a heterotrophic flagellate fed on bacteria with different elemental ratios. Arch Hydrobiol 129:257-271

Porter K, Felg $Y$ (1980) The use of DAPl for identifying and counting aquatic microflora. Limnol Oceanogr 25:943-948

Reiners WA (1986) Complementary models for ecosystems. Am Nat 127:59-73

Sherr BF, Sherr EB, Berman T (1983) Grazing, growth, and ammonium excretion rates of a heterotrophic microflagellate fed with four species of bacteria. Appl Environ Microbiol 45:1196-1201

Sherr BF, Sherr EB, Hopkinson CS (1988) Trophic interactions within pelagic microbial communities: indications of feedback regulation of carbon flow. Hydrobiologia 159:19-26

Solórzano L (1969) Determination of ammonia in natural waters by the phenolhypochlorite method. Limnol Oceanogr 14:799-801

Sterner RW (1990) The ratio of nitrogen to phosphorus resupplied by herbivores: zooplankton and the algal competitive arena. Am Nat 136:209-229

Sterner RW, Elser JJ, Hessen DO (1992) Stoichiometric relationships among producers, consumers and nutrient cycling in pelagic ecosystems. Biogeochemistry 17:49-67

Sterner RW, Hessen DO (1994) Algal nutrient limitation and the nutrition of aquatic herbivores. A Rev Ecol Syst 25: $1-29$

Stevenson LH (1978) A case for bacterial dormancy in aquatic systems. Microb Ecol 4:127-133

Strickland JDH, Parsons TR (1972) A practical handbook of seawater analysis, 2nd edn. Bull Fish Res Bd Can 167:1-310

Tempest DW, Dicks JW, Ellwood DC (1968) Influence of growth condition on the concentration of potassium in Bacillus subtilis var. niger and its possible relationship to cellular ribonucleic acid, teichoic acid and teichuronic acid. Biochem J 106:237-243

Tezuka Y (1990) Bacterial regeneration of ammonum and phosphate as affected by the carbon:nitrogen:phosphorus ratio of organic substrates. Microb Ecol 19:227-238

Thingstad TF (1987) Utilization of N, P, and organic $C$ by heterotrophic bacteria. I. Outline of a chemostat theory with a consistent concept of 'maintenance' metabolısm. Mar Ecol Prog Ser 35:99-109

Turpin DH (1988) Physiological mechanısms in phytoplankton resource competition. In Sandgren CD (ed) Growth and reprodurtive strategies of freshwater phytoplankton. Cambridge Unuv Press, Cambridge, p 316-368

Urabe J (1993) $N$ and P cycling coupled by grazers' activity: food quality and nutrient release by zooplankton. Ecology $74: 2337-2350$

Vadstein O, Jensen A, Olsen Y, Reinertsen H (1988) Growth and phosphoris status of hmnetic phytoplankton and bacteria. Limnol Oceanogr 33:489-503

Vadstein O, Olsen Y (1989) Chemical composition and phosphate uptake kinetics of limnetic bactornal communities cultured in chemostats under phosphorous limitation. Limnol Oceanogr 34:939-946

Vadstein O, Olsen Y, Reinertsen H (1993) The role of planktonic bacteria in phosphorus cycling in lakes - sink and link. Limnol Oceanogr 38:1239-1.544

van Veen JA, Paul EA (1979) Conversion of biovolume measurements of soil organisms, grown under various moisture tensions, to biomass and their nutrient content. Appl Environ Microbiol 37:686-692 